\title{
CHILDREN'S ETHNOFOLLORE OF THE KARAKALPAKS
}

\author{
Kalenderova A.M. \\ Junior Researcher, \\ Karakalpak Scientific Research Institute of Humanities, \\ Karakalpak Branch of the Academy of Sciences of the Republic of Uzbekistan, \\ Nukus. Republic of Karakalpakstan, \\ Uzbekistan
}

Article DOI: https://doi.org/10.36713/epra6862

DOI No: $10.36713 /$ epra6862

\begin{abstract}
Karakalpak lullaby songs refer to children's folklore and display little-studied genre in science. The associations of lullaby songs with national customs and traditions became the actual task in modern folklore. There are lyrics of lullaby with archaic feature and with poetic characteristics. Moreover, the custom folklore features are linked with baby stowing into cradle.
\end{abstract}

KEY WORDS: Lullaby songs, rite, nationality, genre, performance, folklore.

\section{INTRODUCTION}

European scholars of folklorists, ethnographers, doctors, and teachers have been studying lullabies since the first half of the 19th century. A. Vetukhov, G.S. Vinogradov, O.I. Kapitsa, A.N. Martynova, G.A. Bartashevich and others. Researcher of children's folklore M.N. Melnikov believes that these scholars noted the improvisation of the genre in lullabies. The poetics of songs is closely connected with folk psychology, with folk life.

\section{DISCUSSIONS}

Consequently, it can be noted in the European nationality, as such, the rituals for settling a child did not exist. It is characteristic of the Turkic-speaking people. In the Uzbek people, Muzayana Alavia considered ritual poetry and lullabies with a scientific approach. She considered in lullabies the mother's inner world from a historical and educational point of view. In the Karakalpak folklore studies, the collection of folklore materials is associated with names such as K. Ayymbetov, O. Kozhurov, M. Nurmukhamedov, S. Maulenov, Sh. Khozhaniyazov and others. These scholarly collectors were researchers of folklore genres. In the archival materials of K. Aiymbetov, information was found about the 200-year history of the Karakalpak folklore studies. In the 1740s, Muravin and Gladyshev were considered the first collectors of Karakalpak folklore. And after them, in the 1750 s, Rychkov wrote about the Karakalpak folklore. In 1862, Professor Berezin introduced the Karakalpak folklore into the book "Turkish Reader". In 1875 N. Karazin published the Karakalpak fairy tales. K. Ayymbetov and O. Kozhurov tried to develop a classification of folklore genres. Later N. Davkaraev gives a more correct classification of the Karakalpak folklore. More than 60 years of rich material on folklore is kept in the manuscript collection of the Fundamental Library of the UNCANRUz. In science, more or less considered large genres - folk epics. As well as partially small genres - folk songs, fairy tales, proverbs and sayings, etc. Karakalpak children's folklore as a separate science is considered for the first time. Particular attention is drawn to lullabies and the ritual of settling the baby into the cradle.

In the nationality, the so-called "Balany besikke salu" or "Besik toi", where the ceremony "Besik shabyu" is held. Only women and children gathered for this ceremony. The gathered women were placed in a yurt, sitting in two rows and forming a circle. In the middle there was a place for playing with a cradle.

One of those gathered, with a whip in her hands, sat astride the cradle and, imagining that she was sitting on a horse, began the show and spoke. She 
depicted a horse galloping, and then goat-breaking. This rite has a traditional plot and text with which all women are already familiar.

For example:

- Henceforth Allah created what?

- Created the Sun and the Moon,

Into the beauty of the sun and moon,

Created the earth and the green world,

Into the beauty of the earth and the green world,

Created the animal world,

And to ride them,

Allah created mankind....

[Interlinear translation by A.K.]

The given example has a complete finished text, consisting of 51 lyrical lines. The above conspiracy and ritual associated with settling a child has an ancient religious semantic nature. The meaning of the ritual held in the Karakalpak people was that before putting a newborn in the cradle, evil spirits must be expelled. After settling the child into the cradle, the woman who sat astride the cradle skillfully performed the lullaby "Hayu":

Bayu, bayu, my white-faced,

My hat is the dressing girls,

My one-year-old son,

On his head is a green hat,

Beautiful white yurt,

My son is next to his father.

[Interlinear translation by A.K.]

There are many variants of lullaby songs in Karakalpak folklore. In many versions, the theme of pre-revolutionary lullabies is the lament of the mother, the theme of separation, protest against the despotism of her husband, bai, ishan, tsar. But along with the sad motives in the lullabies, there is also hope for a brighter future. Maternal poetry "hayu" in all its richness of repertoire is rich in rhythm, music, motives.

In the science of folklore, the idea of intense change in the poetics of folklore genres under the influence of socio-economic changes was expressed by Yu.M.Sokolov: "Folklore is an echo of the past, but at the same time it is a loud voice of the present". Researchers of oral folk art believe that the poetics of genres changes over time. New characters, new performers, new heroes, a new structure of lyrical lines appear. With the acquisition of a new ideology, the development of the country's social economy, new traditions and customs are born, but national rituals do not lose their antiquity. Modern science is developing and expanding its fields. Those abovementioned rituals and lullabies live and exist today. Folklorists, exploring the genres of oral folk art, continuously work with field records. There are conspiracies among the people associated with putting a child in a cradle. Conspiracies of the modern nature of the "Besikshabyu" ritual consists of several couplets:
Cradle of the Run,

Cradle door on the right,

the owner of the cradle has come,

Go away, devil, go away.

I am a rider on horseback,

I will ride my horse,

My legendary winged horse,

so that he was a falcon horse,

So that the child in the cradle,

The tube was made of gold,

A pot of silver.

[Interlinear translation by A.K.]

This conspiracy consists of eight verses, has a full semantic plot and a performed rite, without losing its historical antiquity, it still exists today. At present, the Besikshabyu ceremony has become very relevant. On the day of "Besik Toy" among the Karakalpaks, women and grandmothers especially prepare for this ceremony. A noble, talented woman with many children is chosen as a rider in the cradle from relatives. And after the performance of the ceremony, she sang the lullaby "Hayu". It should be noted that the Karakalpak people from early times were a people with many children. And the lyrics of lullaby songs did not differ much in content for a boy and for a girl. Many years of experience and analysis of field materials reveal some features of the aesthetics of the world perception. They began to create lullabies for a boy, a girl and twins:

Girl

Bayu, bayu daughter,

As a sunbeam is reflected,

If you sleep well,

That is the mother's calm soul.

My guria, paradise daughter,

My daughter Corals-pearls,

so that you grow up quickly,

And she began to walk on her legs.

Boy

Bai, bai my son,

Allah gave me a foal,

Laid in the cradle,

So that you become strong.

.............................

Well done my hero,

free-for-all My support is strength,

To keep life long,

And it was interesting.

Twins

Bayu, bayu my twins,

With you my eyes in pairs, 
I'll lull you with a lullaby,

I'll put you to sleep myself.

I will sing a lullaby in pairs,

I will fulfill it with bliss,

And when you fell asleep in pairs,

I learned the secrets of the cradle.

[Interlinear translation by A.K.]

The lyric lullabies shown consist of six verses. The analysis of poetics and the plot corresponds to the reality of the sphere of its existence. If we reflect on the very process of the people's inclinations, plots, themes, artistic means correspond to the tastes of modern times, gradually it becomes, folk, losing the author's personality. After all, the original was once created by someone. Modern lullabies in the folk repertoire do not take shape at once, but gradually. In modern folklore studies, the question of the changeability of poetics is associated with the problem of national culture, the peculiarities of its role in modern life. Here it is appropriate to note the opinion expressed in the book "On Russian Folklore": the transformation of a ceremony into a game is a transformation of a genre that has lost its functional specificity with the change in the people's worldview.

\section{CONCLUSIONS}

In conclusion, we can note that the long history of the people is reflected in small genres of Karakalpak folklore. The ritual folklore reflects the wonderful antiquity of the nation.

Wonderful poetics in the repertoire of adults for children. They are filled with maternal love for the child, and this love turns her into a creator - a creator of poetry. Every folklorist should deal not only with the collection and study of texts, but also see the living processes of folk art. And also study and consider the people who have saved them for us.

\section{REFERENCES}

1. Melnikov M.N. Russian children's folklore of Siberia. Moscow, 1970

2. Alavia M. Uzbek folk songs. Tashkent, 1959.

3. Archives of the Ulketanyu Museum. K. Ayimbetov. Vol.-12. Inv. No. 2282. 1959-1962.

4. Field notes of the author. Kanlykul district of the Republic of Karakalpakstan.

5. Aymbetov K. Folk wisdom. Nukus, 1988.

6. Field notes of the author. Recorded from $Z$. Abdinazimova. Nukus.

7. Shafrannikov V. Karakalpak folk songs. Moscow, 1959.

8. Field notes of the author. Recorded from the lips of J. Aminov. Khojelinsky region.

9. Sokolov Yu.M. Russian folklore. Moscow, 1938.

10. Pomerantseva E. About Russian folklore. Publishing house "Science", 1977. 